Article

\title{
Simultaneous Denitrification and Bio-Methanol Production for Sustainable Operation of Biogas Plants
}

\author{
I-Tae Kim 1 \\ Division of Environment and Plant Engineering, Korea Institute of Civil Engineering and Building Technology \\ 283, Goyang-daero, Ilsanseo-gu, Goyang-si, Gyeonggi-do 10223, Korea; itkim@kict.re.kr; Tel.: +82-31-9100885
}

Received: 18 October 2019; Accepted: 19 November 2019; Published: 25 November 2019

\begin{abstract}
This study was conducted to secure the sustainability of biogas plants for generating resources from food waste (FW) leachates, which are prohibited from marine dumping and have been obligated to be completely treated on land since 2013 in South Korea. The aim of this study is to reduce the nitrogen load of the treatment process while producing bio-methanol using digested FW leachate diverted into wastewater treatment plants. By using biogas in conditions where methylobacter $(M$. marinus $88.2 \%$ ) with strong tolerance to highly chlorinated FW leachate dominated, $3.82 \mathrm{mM}$ of methanol production and $56.1 \%$ of total nitrogen $(\mathrm{TN})$ removal were possible. Therefore, the proposed method can contribute to improving the treatment efficiency by accommodating twice the current carried-in FW leachate amount based on TN or by significantly reducing the nitrogen load in the subsequent wastewater treatment process. Moreover, the produced methanol can be an effective alternative for carbon source supply for denitrification in the subsequent process.
\end{abstract}

Keywords: digested food waste leachate; bio methanol production; denitrification; methanotrophs; biogas; wastewater treatment plant

\section{Introduction}

Since 2013 when the marine dumping of food waste (FW) leachate was prohibited in accordance with the London Convention on Prevention of Marine Pollution by Dumping of Wastes and Other Matter in 2009 (which was ratified in 2009), South Korea has moved to treatment in landfills and wastewater treatment plants [1,2]. Of the total FW leachates generated $\left(9498 \mathrm{~m}^{3} \cdot \mathrm{day}^{-1}\right)$ in 2009 , $4007 \mathrm{~m}^{3} \cdot$ day $^{-1}$ was dumped in the sea. This extra load was diverted to land-based facilities such that FW leachates were treated together with other wastes due to the finite capacity of existing treatment plants. This resulted in a deterioration of the quality of the treated water, necessitating the expansion of treatment facilities and thus raising treatment costs [3].

Consequently, the number of biogas plants have increased to convert FWs and FW leachates to resources. Digested, non-biodegradable FW leachates generated from the biogas process are self-treated, mostly in private treatment facilities, whereas those generated in public treatment facilities are treated in urban wastewater treatment plants.

Through the Public Sewage Facility Operation Management Guidelines, the Ministry of Environment restricts the total nitrogen (TN) and total phosphorus (TP) load of FW leachate influent to wastewater treatment plants to within $10 \%$ of the influent sewage load design $[4,5]$.

In parallel with government guidelines, each wastewater treatment plant sets independent influent water quality standards of FW leachate, considering the influent water quality and treatment process characteristics. Digested FW leachate has a low carbon-to-nitrogen $(\mathrm{C} / \mathrm{N})$ ratio due to high non-biodegradable chemical oxygen demand (COD) and ammonia concentrations. Thus, an additional carbon source is required to treat non-biodegradable FW leachates. It is important to identify an applicable carbon source because supplying an external carbon source for denitrification increases 
wastewater treatment costs. Therefore, studies have been conducted to improve the economic efficiency using byproducts from anaerobic digestion processes (such as municipal solid wastes [6,7], FWs [8], and livestock wastes [9-12]) as carbon sources. The FW leachates discharged from FW biogas plants also require an appropriate carbon source due to the low $\mathrm{C} / \mathrm{N}$ ratio (i.e., low carbon content and high nitrogen content), because $\mathrm{CH}_{4}$ and $\mathrm{CO}_{2}$ are discharged from the anaerobic degradation process. However, related studies are insufficient. In a previous study [13], we demonstrated that bio-methanol can be produced by supplementing $\mathrm{NaNO}_{3}$ as a nitrogen source for methanotrophs in the final treated water of a wastewater treatment plant with sufficient trace elements and by using biogas as a carbon source.

To secure the sustainability of converting FWs into resources, this study aimed to reinforce the denitrification of the carbon source by producing bio-methanol using biogas that is self-produced in the anaerobic digester of the digested FW leachate and wastewater treatment plant. This leachate has a high $\mathrm{NaCl}$ content and is transported to and treated in a wastewater treatment plant from the biogas plant of FWs and FW leachates. Methanotrophs use the nitrogen in wastewater as a nitrogen source for growing and producing methanol by oxidizing methane while performing autotrophic denitrification [14]. The methanol produced by methanotrophs is the most widely used carbon source because its denitrification rate is higher than those of many other sources [15]. Furthermore, to contribute to improving the quality of wastewater treatment plant effluent (by reducing the nitrogen load through reducing the high ammonia nitrogen content in digestive fluid), this study examined bio-methanol production and simultaneous denitrification characteristics of urban wastewater treatment plants that perform connected treatment of digestive fluid generated from the FWs and FW leachate biogas plant.

\section{Materials and Methods}

\subsection{Characteristics of the FW Leachate of Biogas Plant}

The digested FW leachates generated from the biogas plant of the Goyang City Biomass Energy Facility are first treated in the plant and are then transported separately to the nearby Samsong Wastewater Treatment Plant and Ilsan Wastewater Treatment Plant for final treatment. This study only examined the digested FW leachate of the biogas plant for FWs and FW leachates flowing into the Ilsan Wastewater Treatment Plant, Goyang City, South Korea. The annual mean influent flow rate in 2018 was $234.6( \pm 36.9) \mathrm{m}^{3}$ day $^{-1}$, the mean $\mathrm{pH}$ was $8.0( \pm 0.5)$, the mean COD concentration was 279.1 $( \pm 116.6) \mathrm{mg} \cdot \mathrm{L}^{-1}$, and the mean TN concentration was $252.2( \pm 99.2) \mathrm{mg} \cdot \mathrm{L}^{-1}$ (Table A1).

\subsection{Cultivation of Methanotrophs}

Soil was collected from a depth of $15-20 \mathrm{~cm}$ from the cover layer soil at a Korean metropolitan landfill (coastal reclaimed land; 20,749,874 $\mathrm{m}^{2} ; 37.57^{\circ} \mathrm{N}, 126.62^{\circ} \mathrm{E}$; [Figure A1]) in Incheon, Korea. Soil samples were collected from three separate points and were uniformly mixed, filtered through a sieve (No. 50; $300 \mu \mathrm{m}$ ) and stored at $4{ }^{\circ} \mathrm{C}$. To cultivate methanotrophs from the collected soil, a modified ammonia and nitrate mineral salt (ANMS) medium was prepared by mixing $\mathrm{NH}_{4} \mathrm{Cl}$ and $\mathrm{KNO}_{3}$, which are nitrogen components of the ammonia mineral salt (AMS) and nitrate mineral salt (NMS) medium [16,17]. The medium contained the following (per $\mathrm{L}$ of distilled water): $0.5 \mathrm{~g} \mathrm{KNO}_{3}$; $0.25 \mathrm{~g} \mathrm{NH}_{4} \mathrm{Cl} ; 1.0 \mathrm{~g} \mathrm{MgSO}_{4} \cdot 7 \mathrm{H}_{2} \mathrm{O} ; 0.2 \mathrm{~g} \mathrm{CaCl}_{2} \cdot \mathrm{H}_{2} \mathrm{O} ; 0.1 \mathrm{~mL} 3.8 \%$ (w/v) Fe-EDTA solution; $0.5 \mathrm{~mL} \mathrm{0.1 \%}$ $(\mathrm{w} / \mathrm{v}) \mathrm{NaMo} \cdot 4 \mathrm{H}_{2} \mathrm{O} ; 26 \mathrm{~g} \mathrm{KH}{ }_{2} \mathrm{PO}_{4} ; 62 \mathrm{~g} \mathrm{Na}_{2} \mathrm{HPO}_{4} \cdot 7\left(\mathrm{H}_{2} \mathrm{O}\right)$. Additionally, $1 \mathrm{~mL}$ of trace element solution was added (per L of distilled solution: $500 \mathrm{mg} \mathrm{FeSO} \cdot \cdot 7 \mathrm{H}_{2} \mathrm{O} ; 400 \mathrm{mg} \mathrm{ZnSO} \cdot 7 \mathrm{H}_{2} \mathrm{O} ; 20 \mathrm{mg} \mathrm{MnCl} 2 \cdot 7 \mathrm{H}_{2} \mathrm{O}$; $50 \mathrm{mg} \mathrm{CoCl} 2 \cdot 6 \mathrm{H}_{2} \mathrm{O} ; 10 \mathrm{mg} \mathrm{NiCl} \cdot 6 \mathrm{H}_{2} \mathrm{O} ; 15 \mathrm{mg} \mathrm{H} \mathrm{BO}_{3} ; 250 \mathrm{mg}$ EDTA). All chemical reagents were of analytical grade and were purchased from Sigma-Aldrich (St. Louis, MO, USA).

Next, $200 \mathrm{~mL}$ modified ANMS medium was added to a $350 \mathrm{~mL}$ conical flask, and $5 \mathrm{~g}$ of the soil sample (prepared as described above) was added for microbial inoculation. The flask was closed on the open end with a silicon stopper and a methanol gas-tight syringe was used to add $20 \%(\mathrm{~V} \%)$ methane to the upper $150 \mathrm{~mL}$ of the headspace. The flask was then sealed with parafilm and cultured 
in a rotary shaker (Lab Champion IS-971R, Champion Laboratories, Albion, IL, USA). Following $24 \mathrm{~h}$ of spinner culture at $250 \mathrm{rpm}$ at $30^{\circ} \mathrm{C}$, the cultured solution was left to settle for $10 \mathrm{~min}$, after which $100 \mathrm{~mL}$ of the supernatant was removed and added to a new $350 \mathrm{~mL}$ conical flask containing NMS medium. The procedure was repeated four times, and the resulting solution containing NMS medium was finally separated using a centrifuge (Dongseo Science Ltd., Dangjin, Centrifuge-416 Korea) at $2700 \times g$. The centrifuged pellet was freeze-dried at $-55^{\circ} \mathrm{C}$ in a freeze dryer (OPERN FDS-12003, Seoul, Korea) for subsequent use. (The steps are summarized in Table A2).

\subsection{Biogas}

To maintain the consistency of the experiment, the biogas was simulated and synthesized to reflect the characteristics of biogas from the digester of a wastewater treatment plant. Biogas consisted of $\mathrm{CH}_{4}(67.0 \%), \mathrm{CO}_{2}(31.0 \%), \mathrm{N}_{2}(1.3 \%)$, and $\mathrm{O}_{2}(0.7 \%)$.

\subsection{Analysis and Measurements}

\subsubsection{Analysis of Microbial Community}

For microbiological analysis, DNA extraction, PCR (Polymerase chain reaction) amplification, and pyrosequencing were performed by Chunlab, Inc. (Seoul, Korea). The 16S rRNA genes of each sample were amplified using barcoded universal primers. To compare each sample's operational taxonomic units, shared operational taxonomic units were obtained by XOR analysis with the CLcommunity program (Chunlab, Inc.). The composition and ratio of microbial species shared by the three sets of samples were calculated (Table A3).

\subsubsection{Analysis of Biogas and Microbial Metabolites}

Biogas and metabolite measurements, microbial community analysis, and water quality analysis followed the methods described in a previous study [13].

\subsubsection{Analysis of Water Quality and Organic Biodegradability}

Analyses of water quality were based on the American Standard Methods for the Examination of Water and Wastewater (23rd ed., American Public Health Association) and EPA Methods (EPA Method 1613). Organic components were analyzed by the colorimetric method and the atomic analysis was performed by atomic-absorption-spectroscopy. The COD fractions method $[18,19]$ was used to evaluate the biodegradability of organic matter.

\subsection{Batch Testing and Assay Device for Anoxic-aerobic and Sequencing Batch Reactor Process}

For the batch test, the freeze-dried cells (described above) were inoculated in a $160 \mathrm{~mL}$ serum bottle (Sigma-Aldrich, USA) with $50 \mathrm{~mL}$ of digested FW leachate (collected from the modified ANMS medium or wastewater treatment plant) as the culture solution to prepare $550 \mathrm{mg} \cdot \mathrm{L}^{-1}$ based on the mixed liquor suspended solids (MLSS). Furthermore, in the batch test, $25 \mathrm{~mL}$ (or $22.7 \%$ ) of the headspace $(110 \mathrm{~mL})$ of the $160 \mathrm{~mL}$ serum bottle was replaced with biogas to adjust the $\mathrm{O}_{2}: \mathrm{CH}_{4}$ ratio to $17.3 \mathrm{~mL}: 18.6 \%$; the same ratio was maintained in the following experiments. Then, the samples were collected and analyzed while being cultured in a shaking incubator at $30^{\circ} \mathrm{C}$ at $150 \mathrm{rpm}$.

The anoxic-aerobic process (Ludzack-Ettinger process [20]) in Figure 1 was used to examine the typical denitrification characteristics of the wastewater. The operating conditions are shown in Table 1 [20]. After measuring the amount of nitrate-nitrogen $\left(\mathrm{NO}_{3}{ }^{-}-\mathrm{N}\right)$ formed in the aerobic tank when methanol was injected as a carbon source for denitrification, $3.0 \mathrm{~g}$ methanol per $1 \mathrm{~g}$ of $\mathrm{NO}_{3}{ }^{-}-\mathrm{N}$ was injected, based on the empirical reaction equation and experimental value (Table A4) as suggested by McCart et al. [21]. 


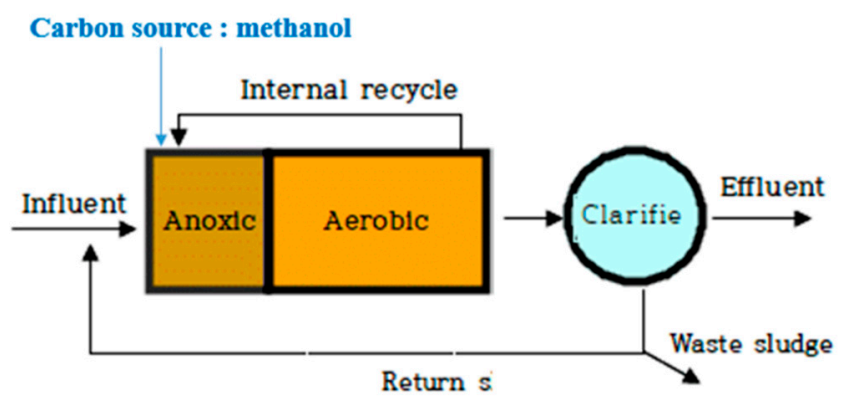

Figure 1. Anoxic-aerobic denitrification (Ludzack-Ettinger) process (pre-denitrification).

Table 1. Operation conditions of the anoxic-aerobic (Ludzack-Ettinger) process.

\begin{tabular}{|c|c|c|c|}
\hline Item & MLSS $\left(\mathrm{mg} \cdot \mathrm{L}^{-1}\right)$ & Inflow $\left(\mathrm{L} \cdot\right.$ day $\left.^{-1}\right)$ & HRT (h) \\
\hline Oxic & $2200-2300$ & 24 & 4.3 \\
\hline Anoxic & $2300-2400$ & & 1.7 \\
\hline
\end{tabular}

Note: Internal recycle: 3Q, HRT—hydraulic retention time, MLSS—mixed liquor suspended solids.

The sequencing batch reactor (SBR) was equipped with a stirrer, a gas supplier, and gas pressure gauges as shown in Figure 2. The SBR was operated with a residence time of $6 \mathrm{~h}$ while stirring at $20-25^{\circ} \mathrm{C}$ at $150 \mathrm{rpm}$, and with the settling time of $30 \mathrm{~min}$. The microbes increased by proliferation and were discharged with a sludge retention time (SRT) of 15 days, while the MLSS was maintained at $3700-4400 \mathrm{mg} \cdot \mathrm{L}^{-1}$. The biogas was automatically injected from the gas tank while monitoring biogas and oxygen consumption by the pressure sensor in the bioreactor.

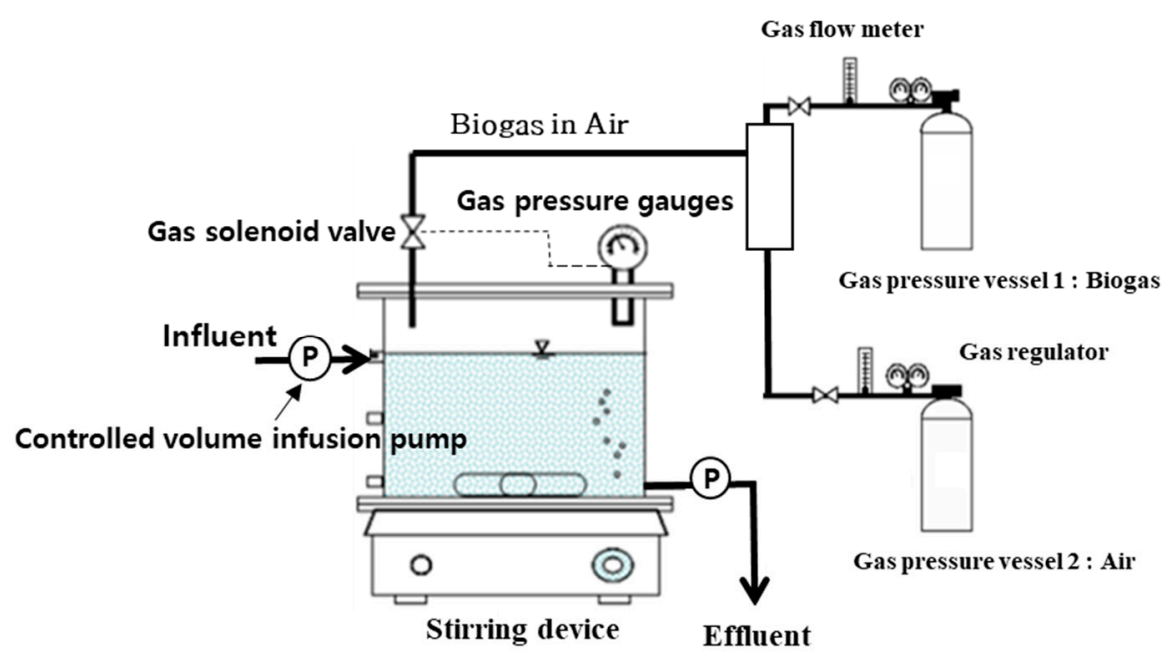

Figure 2. Schematic diagram of the methane and methanol dependent microbial bacteria consortium sequencing batch reactor (SBR) system.

\section{Results and Discussion}

\subsection{Water Quality and Biological Treatment Characteristics of FW Leachate}

The FWs and FW leachates flowing into the FW biogas plant progress through the anaerobic digestion process were composed of; (1) leachate (including organic matter), (2) biogas, and (3) stabilized digestion sludge, before being discharged from the digester. Digested FW leachate cannot be directly discharged due to the high residual organic matter concentration. Thus, it undergoes aerobic treatment or secondary treatment (such as advanced oxidation process [AOP]) before being transported 
to the wastewater treatment plant for retreatment in accordance with the water quality standards for public waters and effluent. The Ilsan Wastewater Treatment Plant only accepts carried-in digested FW leachate in which the nitrogen load has been treated to below $7 \mathrm{~kg} \cdot$ day $^{-1}$ or $300 \mathrm{~m}^{3} \cdot$ day $^{-1}$ by applying the TN criterion. This is because it is difficult to treat nitrogen due to the water quality characteristics of the influent and the treatment process. As shown in Table 2, the TN concentration was $297 \mathrm{mg} \cdot \mathrm{L}^{-1}$ at $\mathrm{pH} 8.1$, which is higher than the average (annual mean value) concentration in sewage influent of 53.8 $( \pm 13.0) \mathrm{mg} \cdot \mathrm{L}^{-1}$, and the $\mathrm{NH}_{4}-\mathrm{N}$ concentration was $236 \mathrm{mg} \cdot \mathrm{L}^{-1}$, accounting for the majority of the TN. Furthermore, the influent digested $\mathrm{FW}$ leachate had a very high $\mathrm{NaCl}$ content of $0.73 \%$, unlike other wastewater types.

Table 2. Water quality characteristics of food waste (FW) leachate, digested FW leachate after conversion to biogas, and FW leachate carried in the wastewater treatment plant. SS-suspended solids, COD—chemical oxygen demand, TN—-total nitrogen, TP — total phosphorus, WC - water content, STP—sewage treatment plant.

\begin{tabular}{|c|c|c|c|c|c|c|c|c|}
\hline & $\mathrm{pH}$ & $\begin{array}{c}\text { SS } \\
\left(\mathrm{mg} \cdot \mathrm{L}^{-1}\right)\end{array}$ & $\underset{\left(\mathrm{mg} \cdot \mathrm{L}^{-1}\right)}{\mathrm{COD}}$ & $\begin{array}{c}\mathrm{NH}_{4}-\mathrm{N} \\
\left(\mathrm{mg} \cdot \mathrm{L}^{-1}\right)\end{array}$ & $\begin{array}{c}\mathrm{TN} \\
\left(\mathrm{mg} \cdot \mathrm{L}^{-1}\right)\end{array}$ & $\begin{array}{c}\mathrm{TP} \\
\left(\mathrm{mg} \cdot \mathrm{L}^{-1}\right)\end{array}$ & $\begin{array}{c}\mathrm{NaCl} \\
(\%)\end{array}$ & WC (\%) \\
\hline $\begin{array}{c}\text { FW } \\
\text { leachate }\end{array}$ & $\begin{array}{c}4.2 \\
( \pm 0.13)\end{array}$ & $\begin{array}{c}98,457 \\
( \pm 239.32)\end{array}$ & $\begin{array}{c}148,605 \\
( \pm 612.4)\end{array}$ & $\begin{array}{c}648 \\
( \pm 23.6)\end{array}$ & $\begin{array}{c}3729 \\
( \pm 116.2)\end{array}$ & $\begin{array}{c}428 \\
( \pm 31.2)\end{array}$ & $\begin{array}{c}0.52 \\
( \pm 0.12)\end{array}$ & $\begin{array}{c}89.6 \\
( \pm 3.2)\end{array}$ \\
\hline Digested & 8.2 & 56,032 & 44,289 & 1823 & 3654 & 317 & 0.95 & 87.3 \\
\hline leachate & $( \pm 0.11)$ & $( \pm 311.3)$ & $( \pm 276.4)$ & $( \pm 87.5)$ & $( \pm 98.5)$ & $( \pm 24.3)$ & $( \pm 0.07)$ & $( \pm 2.4)$ \\
\hline $\begin{array}{l}\text { Carried } \\
\text { in STP }\end{array}$ & $\begin{array}{c}8.1 \\
( \pm 0.08)\end{array}$ & $\begin{array}{c}230 \\
( \pm 13.7)\end{array}$ & $\begin{array}{c}279 \\
( \pm 29.7)\end{array}$ & $\begin{array}{c}236 \\
( \pm 18.6)\end{array}$ & $\begin{array}{c}297 \\
( \pm 21.4)\end{array}$ & $5( \pm 1.1)$ & $\begin{array}{c}0.73 \\
( \pm 0.09)\end{array}$ & $\begin{array}{c}89.7 \\
( \pm 2.6)\end{array}$ \\
\hline
\end{tabular}

Note: The $\mathrm{NaCl}$ value was converted from the measured concentration of chlorine ions, using the following formula: salinity $(\%)=0.000180665 \mathrm{Cl}^{-}\left(\mathrm{mg} \cdot \mathrm{L}^{-1}\right)$.

Organic matter that is easily degradable through anaerobic digestion was mostly degraded and the soluble biodegradable chemical oxygen demand (BDCOD) and non-biodegradable chemical oxygen demand (NBDCOD) in the influent digested FW leachate had concentrations of $<1 \%$. The total BDCOD of the influent digested FW leachate in the wastewater treatment plant accounted for $28.7 \%$ of the COD, and NBDCOD accounted for the remaining $71.3 \%$ of the COD (Table 3). It can be seen that the majority of these FW leachates are difficult to remove by biological treatment methods in the wastewater treatment process and have components that are disadvantageous for subsequent water treatment and effluent.

Table 3. Analysis of water quality characteristics by biological treatment of leachate by the food waste (FW) leachate treatment step (unit: \%). BDCOD—biodegradable chemical oxygen demand, NBDCOD—non-biodegradable chemical oxygen demand.

\begin{tabular}{ccccccc}
\hline & $\begin{array}{c}\text { Soluble } \\
\text { BDCOD }\end{array}$ & $\begin{array}{c}\text { Soluble } \\
\text { NBDCOD }\end{array}$ & $\begin{array}{c}\text { Particle } \\
\text { BDCOD }\end{array}$ & $\begin{array}{c}\text { Particle } \\
\text { NBDCOD }\end{array}$ & $\begin{array}{c}\text { Total } \\
\text { BDCOD }\end{array}$ & $\begin{array}{c}\text { Total } \\
\text { NBDCOD }\end{array}$ \\
\hline FW leachate & 22.4 & 6.4 & 39.5 & 31.7 & 61.9 & 38.1 \\
Digested leachate & 0.6 & 0.3 & 33.3 & 65.8 & 33.9 & 65.8 \\
Carried in STP & 0.9 & 0.7 & 27.8 & 70.6 & 28.7 & 71.3 \\
\hline
\end{tabular}

Note: Data represent means from two replicates.

When the denitrification experiment was conducted using the anoxic/aerobic denitrification process for the influent digested FW leachate of the wastewater treatment plant showing these characteristics, only $12.7 \%$ of the influent $\mathrm{TN}$ was removed, as shown in Table 4 . When methanol was input to the anoxic process as a carbon source required in correspondence to the additionally generated nitrate $\left(\mathrm{NO}_{3}{ }^{-}-\mathrm{N}\right)$ produced by nitrification, the TN removal rate increased to $39.1 \%$. The above results of food waste leachate analysis show that the organic acid in anaerobically digested FW leachates, which is available as a carbon source, is mostly degraded and composed of non-biodegradable organic matter, 
thus raising the $\mathrm{pH}$ of the surrounding area to eight and necessitating further chemical treatments. Therefore, this negative environmental impact makes the process less sustainable as a method for generating resources from biogas.

Table 4. Denitrification characteristics of the influent digested food waste (FW) leachate in the wastewater treatment plant (mean values of 38 day operation results).

\begin{tabular}{cccccc}
\hline \multirow{2}{*}{ Item } & Influent $(\mathrm{mg} / \mathrm{L})$ & \multicolumn{2}{c}{ Anoxic/Aerobic Process } & \multicolumn{2}{c}{$\begin{array}{c}\text { Methanol Addition in Anoxic } \\
\text { Reactor }\end{array}$} \\
\cline { 3 - 6 } & & $\begin{array}{c}\text { Effluent conc. } \\
(\mathrm{mg} / \mathrm{L})\end{array}$ & Removal $(\%)$ & $\begin{array}{c}\text { Effluent Conc. } \\
(\mathrm{mg} / \mathrm{L})\end{array}$ & Removal (\%) \\
\hline $\mathrm{COD}$ & $263.4( \pm 23.7)$ & $205.5( \pm 16.5)$ & $22.0( \pm 3.4)$ & $198.6( \pm 16.7)$ & $24.6( \pm 2.8)$ \\
\hline $\mathrm{NH}_{3}-\mathrm{N}$ & $228.2( \pm 19.3)$ & $123.4( \pm 18.8)$ & $45.9( \pm 4.2)$ & $126.3( \pm 14.5)$ & $98.9( \pm 4.1)$ \\
\hline $\mathrm{NO}_{3}{ }^{-}-\mathrm{N}$ & $71.6( \pm 9.4)$ & $142.6( \pm 20.3)$ & $\begin{array}{c}12.7 \text { as T-N } \\
( \pm 3.6)\end{array}$ & $63.5( \pm 9.3)$ & $\begin{array}{c}39.1 \text { as T-N } \\
( \pm 4.6)\end{array}$ \\
\hline $\mathrm{PO}_{4}{ }^{-3}-\mathrm{P}$ & $7.6( \pm 8.2)$ & $4.8( \pm 3.2)$ & $36.8( \pm 4.1)$ & $3.4( \pm 1.6)$ & $5.3( \pm 1.7)$ \\
\hline
\end{tabular}

\subsection{Change in the Characteristics of the Microbial Community in the Culture Medium}

When the methanotrophs were cultured using the digested FW leachate with the modified ANMS described in 2.2 and the characteristics described in 3.1 as culture sources, the Methylomonas, Methylococcus, Methylobacter, Methylomonas_f_uc, and Methylosarcina genera were cultured in the landfill soil as shown in Figure 3.

In the case of the methanotrophs cultured in the first modified ANMS, Methylomonas methanica was dominant (36.9\%), followed by Methylomonas sp. (18.1\%), and Methylobacter marinus $(12.3 \%)$. In contrast, when the methanotrophs in the modified ANMS were cultured using the digested FW leachate as the culture solution, the Methylomonas genus did not appear, and Methylobacter marinus (which are marine methane-oxidizing bacteria) accounted for most of the constituent species at $88.2 \%$ of methanotrophs [22,23]. The reason that Methylobacter marinus was detected as a dominant species in this study seemed to be that the urban waste landfill (which was the soil sampling point for seeding) is reclaimed marine land, and the $\mathrm{NaCl}$ concentration of the digested $\mathrm{FW}$ leachate was $0.52-0.95 \%$ higher than that of other wastewater (Table 2).

According to Bowman et al. and Wartiainen et al., the salinity range for optimal growth was wide $(0.0-3.0 \% \mathrm{NaCl})$ [23-25]. Therefore, it was verified that the Methylobacter marinus cultivated as a dominant species in this study can grow in a wide range of salinities and play the role of a dominant species among methanotrophs when $\mathrm{FW}$ leachate with a high $\mathrm{NaCl}$ content is used.

Methylobacter marinus is a marine methane-oxidizing bacterium that commonly appears in other studies on marine methanotrophs $[25,26]$. No further studies have been conducted on this species and no clear taxonomic status has been found until now. Recently, Flynn et al. found the genome sequence of Methylobacter marinus A45 [27]. Furthermore, it is presumed that the species composition was simplified to the unequalled dominance of Methylobacter marinus because $\mathrm{NaCl}$ suppresses the expression of methanol dehydrogenase (MDH), which oxidizes methanol generated by methanotrophs to formaldehyde, thus inhibiting the formaldehyde metabolism of methanotrophs which do not have a wide-ranging tolerance to $\mathrm{NaCl}$. A possible explanation for this may be that $\mathrm{NaCl}$ acts as a $\mathrm{MDH}$ expression inhibitor to prevent transformation of methanol into formaldehyde during methanol production using methanotrophs [28-33]. 


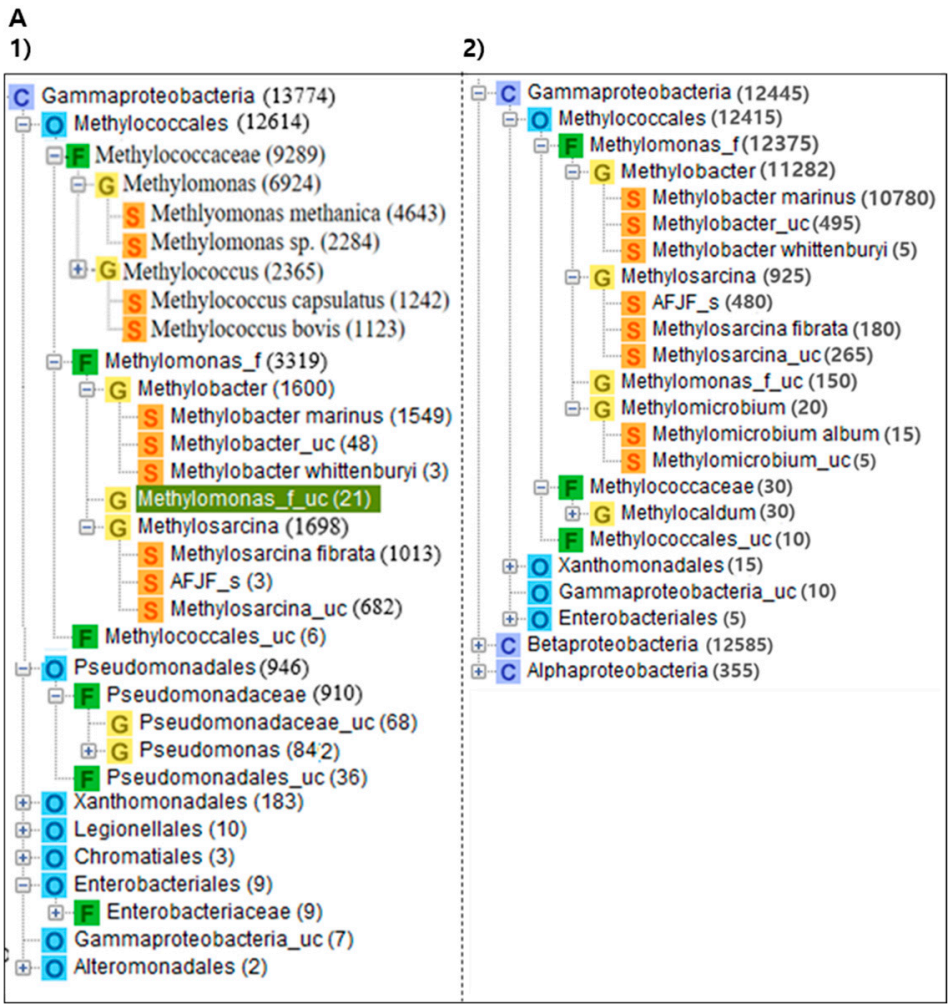

B

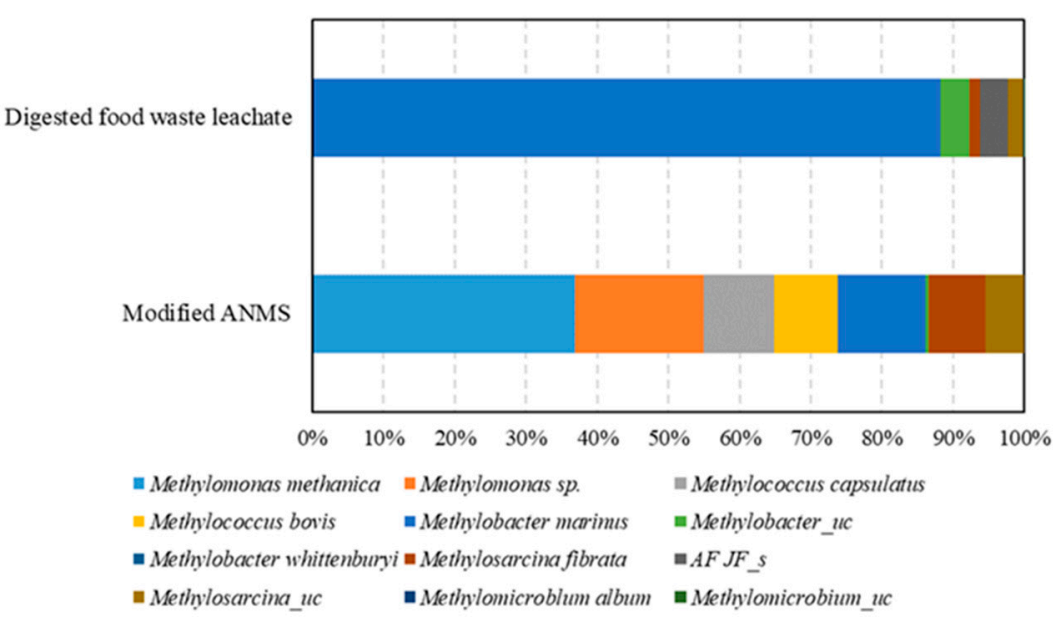

Figure 3. Schematic diagram of the constituent species of methanotrophs from the; (A) (1) modified ammonia and nitrate mineral salt (ANMS) medium and (2) digested food waste (FW) leachate, and (B) the relative ratios of constituent methanotrophs species.

\subsection{Methanol Production from Digested FW Leachate by Methanotrophs}

Table 5 and Figure 4 outlines the methanol and formaldehyde production from methanotrophs and biogas based on the modified ANMS medium and digested FW leachate. After $24 \mathrm{~h}$ culturing in a LMSS concentration of $550 \mathrm{mg} \cdot \mathrm{L}^{-1}$, methanol was produced at $4.11 \mathrm{mM}$ (COD converted value: $197.54 \mathrm{mg} \cdot \mathrm{L}^{-1}$ ) and $3.82 \mathrm{mM}$ (COD converted value $131.90 \mathrm{mg} \cdot \mathrm{L}^{-1}$ ) in the modified ANMS medium and the digested FW leachate, respectively. The digested FW leachate produced somewhat less methanol from methanotrophs than the modified ANMS medium. The ratio of methanol in the total metabolites was $80.3 \%$, which was higher than the modified ANMS medium (60.3\%). Thus, the digested FW leachate had only a minimal disadvantage compared to the modified ANMS medium in terms of methanol formation. 
Table 5. Production of methanotrophs metabolite (methanol, formaldehyde, formate) in modified ammonia and nitrate mineral salt (ANMS) medium and digested food waste (FW) leachate (for $24 \mathrm{~h}$ ).

\begin{tabular}{ccccc}
\hline Culture Medium & Methanol $(\mathbf{m M})$ & $\begin{array}{c}\text { Formaldehyde } \\
(\mathbf{m M})\end{array}$ & Formate $(\mathbf{m M})$ & $\begin{array}{c}\text { Total Metabolite } \\
(\mathbf{m M})\end{array}$ \\
\hline $\begin{array}{c}\text { Modified ANMS } \\
\text { medium } \\
\begin{array}{c}\text { Digested FW } \\
\text { leachate }\end{array}\end{array}$ & $4.11( \pm 0.13)$ & $1.98( \pm 0.12)$ & $0.73( \pm 0.08)$ & $6.82( \pm 0.19)$ \\
\hline
\end{tabular}

Note: Data represents means from three replicates \pm standard deviations.

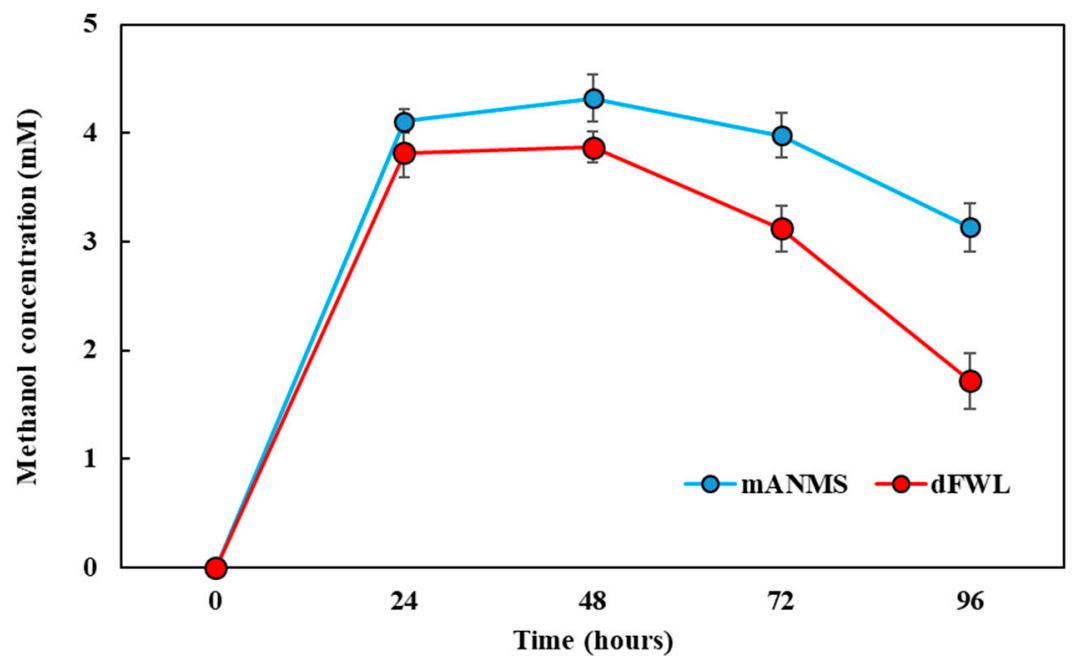

Figure 4. Temporal changes in methanol production from methanotrophs with modified ammonia and nitrate mineral salt (ANMS) medium (mANMS) and digested food waste (FW) leachate (dFWL) as culture solutions. Data represent means from three replicates \pm standard deviations.

\subsection{Denitrification Characteristics of Digested FW Leachate}

Anthony [34] revealed experimentally that methane-oxidizing bacteria have relatively high nitrogen demand during growth and ingested $0.25 \mathrm{~mol}$ of nitrogen to assimilate $1 \mathrm{~mol}$ of carbon from methane. Furthermore, the nitrogen and phosphorus contents in the methanotroph sludge showed that the TN content in the activated sludge of the wastewater treatment plant was $5.34 \%$ on average, but was $8.53 \%$ in the methane-oxidizing bacteria sludge. This result suggests that methanotroph growth has a high nitrogen demand [35].

Furthermore, in the metabolism process of methanotrophs, ammonia was oxidized to $\mathrm{N}_{2} \mathrm{O}$ through $\mathrm{NH}_{3} \mathrm{OH}$ in the same path as that of the ammonia oxidation of ammonia-oxidizing bacteria (AOB) by the methane monooxygenase (MMO), which is a methane-oxidizing enzyme [34,35]. Consequently, the tendency of removing high concentration ammonium and some nitrates in the digested FW leachate by using methanotrophs and biogas was verified. As shown in Figure 5, there were decreases in ammonia by $73.2 \%$ (from $276 \mathrm{mg} \cdot \mathrm{L}^{-1}$ to $74 \mathrm{mg} \cdot \mathrm{L}^{-1}$ ), nitrate by $61.0 \%$ (from $82 \mathrm{mg} \cdot \mathrm{L}^{-1}$ to $32 \mathrm{mg} \cdot \mathrm{L}^{-1}$ ), and TN by $67.4 \%$ (from $374 \mathrm{mg} \cdot \mathrm{L}^{-1}$ to $122 \mathrm{mg} \cdot \mathrm{L}^{-1}$ ) in $6 \mathrm{~h}$. In other words, the method applied to this experiment was verified as an effective means to increase methanol as a carbon source for the denitrification of digested FW leachate with low biodegradability and high $\mathrm{NaCl}$ concentration, and also for the denitrification of the subsequent sewage treatment process. 


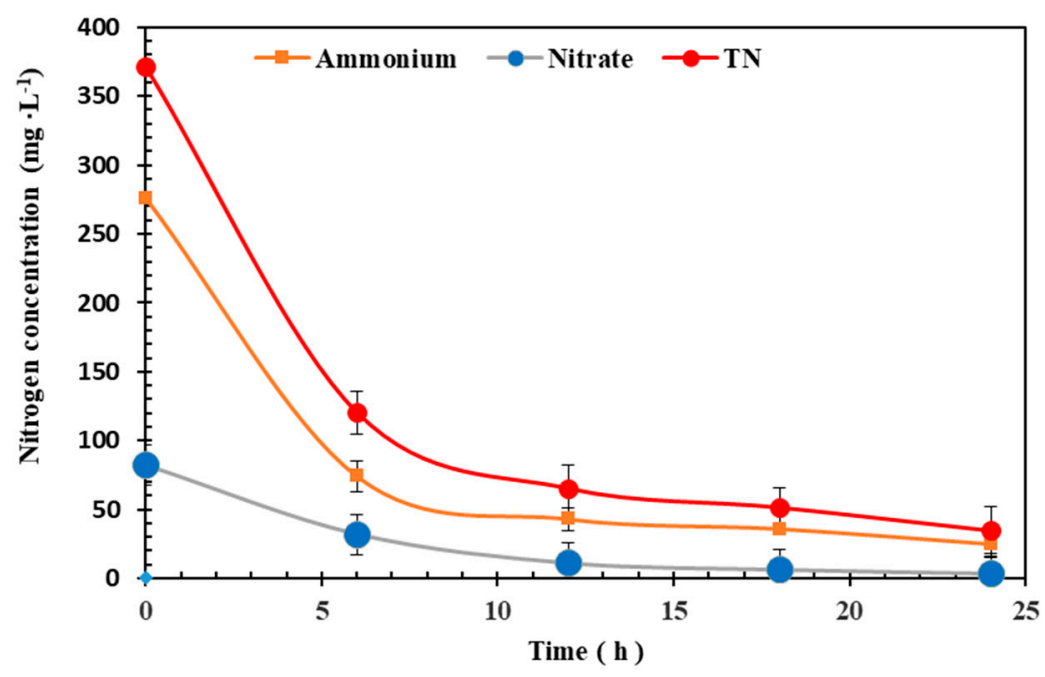

Figure 5. Changes in nitrogen concentrations in digested food waste (FW) leachate with methanotrophs and biogas. TN—total nitrogen. Note: Data represents means from three replicates \pm standard deviations.

Based on the denitrification characteristics revealed through the batch test, the characteristics of denitrification from the digested FW leachate were analyzed by continuously operating the SBR system (Figure 1) for $37 \mathrm{~d}$ (based on $6 \mathrm{~h}$ operation per session), with the digested FW leachate flowing into the wastewater treatment plant. The results are shown in Figure 6.

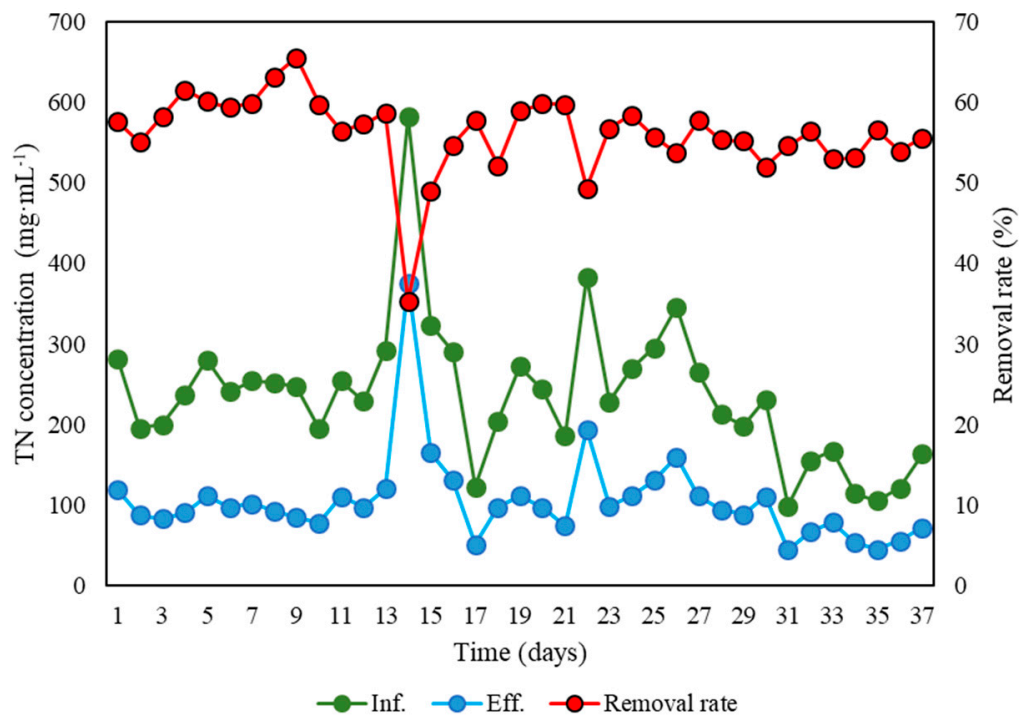

Figure 6. Results of the continuous experiment of SBR (operation time: $6 \mathrm{~h}$ ) for the denitrification characteristics of digested food waste (FW) leachate by methanotrophs and biogas. Inf.-influent, Eff.- effluent, TN-total nitrogen.

Based on TN, the mean influent concentration was $236.4( \pm 87.2) \mathrm{mg} \mathrm{L}^{-1}$, the mean effluent concentration was $105.7( \pm 56.1) \mathrm{mg} \cdot \mathrm{L}^{-1}$, and the mean removal rate was $56.1 \%( \pm 4.9)$. Hence, a much higher TN removal rate than the $39.1 \%$ (Table 4 ) in 3.1 when methanol was additionally supplied to the anoxic/aerobic denitrification process was obtained. Therefore, the proposed method can contribute to improving the treatment efficiency by accommodating twice the current influent FW leachate amount (based on TN) or by significantly reducing the nitrogen load in the subsequent wastewater treatment process. Moreover, it can be an alternative to improve the denitrification efficiency by adding the 
generated methanol to the influent water as a carbon source for denitrification. In this case, the removal rate decreased when ammonium-which accounts for most of the TN component-increased above a certain level. This was presumably caused by two toxic intermediates of ammonium oxidation by methanotrophs, hydroxylamine $\left(\mathrm{NH}_{2} \mathrm{OH}\right)$ and nitrite, interfering with the normal operation of the detoxification mechanisms, or by complex causes arising from the energy consumed by methanotrophs during the detoxification of hydroxylamine [36-38].

Further studies are required to investigate the primary treatment method for high-concentration ammonia wastewater in biogas plants, which are the source as well as the methanol production metabolism characteristics for methanotrophs with a high $\mathrm{NaCl}$ tolerance.

\section{Conclusions}

Bio-methanol was produced at $3.82 \mathrm{mM}\left(\mathrm{COD} ; 131.90 \mathrm{mg} \cdot \mathrm{L}^{-1}\right.$ ) from FW leachates having few

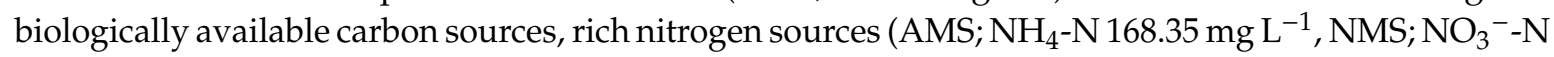
$613 \mathrm{mg} \cdot \mathrm{L}^{-1}$ ), and an mean content of $0.73 \%$ or higher of digested $\mathrm{NaCl}$ (such as methanotroph culture medium), by using biogas with methylobacter (M. marinus) as the dominant methanotroph species. Furthermore, up to $56.1 \%$ of the TN in the FW leachates could be removed by oxidizing ammonia through nitrogen assimilation of methanotrophs and methane monooxygenase (MMO). Therefore, the proposed method can contribute to improving the treatment efficiency by accommodating twice the current influent FW leachate amount based on TN or by significantly reducing the nitrogen load in the subsequent wastewater treatment process. Moreover, it can be a new alternative for the sustainable operation of biogas plants to improve the denitrification efficiency by adding the generated methanol to the influent water as a carbon source for denitrification.

Funding: This work was supported by a major project of the Korea Institute of Civil Engineering and Building Technology, grant number 20190152-001

Acknowledgments: I would like to thank Sungkyunkwan University Center for zero emission technology (https://enc.skku.edu/enc/lab/environ_tech.do), and analysis of metabolites and water quality, CCHUNLAB (chunlab.com) for support of bioinfomatic information for microbiology and Editage (www.editage.co.kr) for English language editing.

Conflicts of Interest: The authors declare no conflicts of interest.

\section{Appendix A}

\section{Tables and Figures}

\section{Simultaneous Denitrification and Bio-methanol Production for Sustainable Operation of Biogas Plants}

Table A1. Influent amount of digested FW leachate and water quality for target biogas plant in the wastewater treatment plant. BOD—Biological oxygen demand, COD—Chemical oxygen demand, SS—suspended solids, TN—total nitrogen, TP—total phosphorus.

\begin{tabular}{ccccccccc}
\hline & Flow & $\begin{array}{c}\text { Water } \\
\text { Temp. }\end{array}$ & PH & BOD & COD & SS & TN & TP \\
\hline Mean & 234.6 & 14.6 & 8.0 & 171.5 & 279.1 & 245.3 & 252.2 & 4.9 \\
N & 302.0 & 43.0 & 43.0 & 43.0 & 43.0 & 43.0 & 43.0 & 42.0 \\
SD & 36.9 & 6.8 & 0.5 & 99.1 & 116.6 & 134.6 & 99.2 & 3.5 \\
\hline
\end{tabular}


Table A2. Methanotrophs enrichment procedure.

1. Collect soil from below $15 \mathrm{~cm}$ depth in the waste landfill site

2. Sieve (\#50) collected soil to remove debris

3. $5 \mathrm{~g}$ soil added to $200 \mathrm{~mL}$ NMS medium in $350 \mathrm{~mL}$ flask

4. Capped and sealed

5. Inject methane into the headspace $(150 \mathrm{~mL})$ of the flask $\left(20 \% \mathrm{CH}_{4}\right.$ by volume $)$

6. Incubate for $1 \mathrm{~d}$ at $250 \mathrm{rpm}$ and $30^{\circ} \mathrm{C}$

7. Settle for $10 \mathrm{~min}$ and decant the supernatant

8. Add $100 \mathrm{~mL}$ supernatant to $100 \mathrm{~mL}$ of NMS medium in a $350 \mathrm{~mL}$ flask

9. Conduct steps (4)-(7)

10. Repeat steps (8)-(9) four times

11. Centrifuge the supernatant for $5 \mathrm{~min}$ at $2,700 \times g$

12. Freeze and dry of centrifuged solids at $-55^{\circ} \mathrm{C}$ and store in refrigerator at $4{ }^{\circ} \mathrm{C}$ for subsequent use.

Table A3. Conditions used in touch-down Image result for polymerase chain reaction (PCR) for microbial community analysis.

\begin{tabular}{cccc}
\hline Step & Temperature $\left({ }^{\circ} \mathbf{C}\right)$ & Time $(\mathbf{s})$ & Cycle \\
\hline Initial denaturation & 94 & 300 & - \\
Denaturation & 94 & 30 & 10 \\
Annealing & 60 & 45 & $\left(-0.5^{\circ} \mathrm{C} /\right.$ cycle $)$ \\
Extension & 72 & 90 & \\
Denaturation & 94 & 30 & 20 \\
Annealing & 55 & 45 & - \\
Extension & 72 & 90 & - \\
Hold & 4 & $\infty$ & \\
\hline
\end{tabular}

Table A4. Basis of calculating the methanol demand required for nitrate denitrification [a].

McCarty et al. (1969) experimentally measured the cell production using methanol as carbon source and established the empirical reaction equations of the denitrification process as follows:

$$
\begin{gathered}
\mathrm{NO}_{3}^{-}+1.08 \mathrm{CH}_{3} \mathrm{OH}+0.24 \mathrm{H}_{2} \mathrm{CO}_{3} \rightarrow 0.056 \mathrm{C}_{5} \mathrm{H}_{7} \mathrm{O}_{2} \mathrm{~N}+0.47 \mathrm{~N}_{2}+1.68 \mathrm{H}_{2}+\mathrm{HCO}_{3}^{-} \\
\mathrm{NO}_{2}^{-}+0.67 \mathrm{CH}_{3} \mathrm{OH}+0.53 \mathrm{H}_{2} \mathrm{CO}_{3} \rightarrow 0.04 \mathrm{C}_{5} \mathrm{H}_{7} \mathrm{O}_{2} \mathrm{~N}+0.48 \mathrm{~N}_{2}+1.23 \mathrm{H}_{2}+\mathrm{HCO}_{3}^{-} \\
\mathrm{O}_{2}+0.93 \mathrm{CH}_{3} \mathrm{OH}+0.56 \mathrm{NO}_{3}^{-} \rightarrow 0.056 \mathrm{C}_{5} \mathrm{H}_{7} \mathrm{O}_{2} \mathrm{~N}+1.04 \mathrm{H}_{2} \mathrm{O}+0.59 \mathrm{H}_{2} \mathrm{CO}_{3}+0.56 \mathrm{HCO}_{3}^{-}
\end{gathered}
$$

In Equation (1), the theoretical methanol amount required to remove $1 \mathrm{~g}$ of nitrate nitrogen is approximately $2.47 \mathrm{~g}$, and the experimental value was $2.5-3.0 \mathrm{~g} / \mathrm{g} \mathrm{NO}_{3}{ }^{-}-\mathrm{N}$.

[a] McCarty, Perry L., Beck, Louis, St. Amant, Percy, Biological denitrification of wastewaters by addition of organic materials, Proceedings of the 24th Industrial Waste Conference, Engineering Technical Reports Collection, Purdue University, 1969. 1271-1285. http://earchives.lib.purdue.edu/u?/engext,16392. 


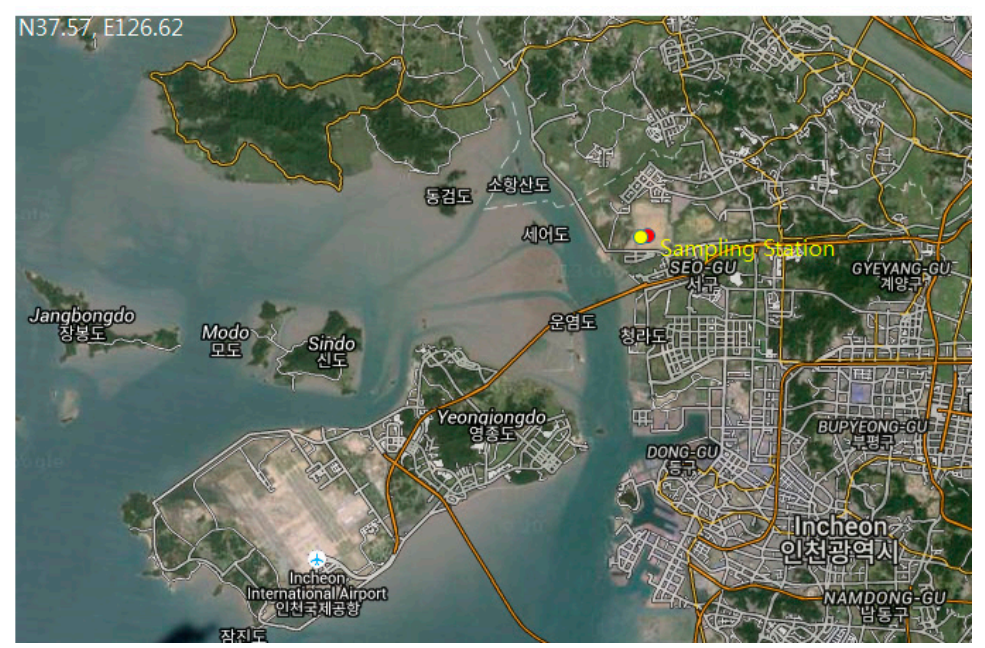

Figure A1. Location of soil sample collection in the metropolitan landfill (coastal reclaimed land, $\left.20,749,874 \mathrm{~m}^{2}\right)$.

\section{References}

1. International Marine Organization. Convention on the Prevention of Marine Pollution by Dumping of Wastes and other Matter; IMO: London, UK, 1996.

2. Ministry of Environment. Research on the Improvement Measures and Direction in Management Policy of FW; Ministry of Environment: Sejong City, Korea, 2012.

3. Ministry of Environment. General Information of FW Treatment Facilities; Ministry of Environment: Sejong City, Korea, 2013.

4. Ministry of Environment. A Business Index of Operation Management to Public Wastewater Treatment Facilities; Ministry of Environment: Sejong City, Korea, 2013.

5. Ministry of Environment. A Business Index of Operation Management to Public Wastewater Treatment Facilities; Ministry of Environment: Sejong City, Korea, 2014.

6. Krupp, M.; Schubert, J.; Widmann, R. Feasibility study for co-digestion of sewage sludge with OFMSW on two wastewater treatment plants in Germany. Waste Manag. 2005, 25, 393-399. [CrossRef]

7. Bolzonella, D.; Battistoni, P.; Susinii, C.; Cecchi, F. Anaerobic codigestion of waste activated sludge and OFMSW: The experiences of Viareggio and Treviso plants (Italy). Water Sci. Technol. 2006, 53, $203-211$. [CrossRef]

8. Iacovidou, E.; Ohandja, D.-G.; Voulvoulis, N. FW co-digestion with sewage sludge-Realising its potential in the UK. J. Environ. Manag. 2012, 112, 267-274. [CrossRef] [PubMed]

9. Murto, M.; Björnsson, L.; Mattiasson, B. Impact of food industrial waste on anaerobic co-digestion of sewage sludge and pig manure. J. Environ. Manag. 2004, 70, 101-107. [CrossRef] [PubMed]

10. Luste, S.; Luostarinen, S. Anaerobic co-digestion of meat-processing by-products and sewage sludge-Effect of hygienization and organic loading rate. Bioresour. Technol. 2010, 101, 2657-2664. [CrossRef] [PubMed]

11. Cuetos, M.J.; Gómez, X.; Otero, M.; Morán, A. Anaerobic digestion of solid slaughterhouse waste (SHW) at laboratory scale: Influence of co-digestion with the organic fraction of municipal solid waste (OFMSW). Biochem. Eng. J. 2008, 40, 99-106. [CrossRef]

12. Marañón, E.; Castrillón, L.; Quiroga, G.; Fernández-Nava, Y.; Gómez, L.; García, M.M. Co-digestion of cattle manure with FW and sludge to increase biogas production. Waste Manag. 2012, 32, 1821-1825. [CrossRef] [PubMed]

13. Kim, I.-T.; Yoo, Y.-S.; Yoon, Y.-H.; Lee, Y.-E.; Jo, J.-H.; Jeong, W.; Kim, K.-S. Bio-methanol production using treated domestic wastewater with mixed methanotroph species and anaerobic digester biogas. Water 2018, 10, 1414. [CrossRef]

14. Mechsner, K.L.; Hamer, G. Denitrification by Methanotrophic, Methylotrophic Bacterial Associations in Aquatic Environments; Plenum Press: New York, NY, USA, 1983; pp. 257-271. 
15. Tam, Y.F.; Wong, Y.S. Effect of Exogenous Carbon Sources on Removal of Inorganic Nutrient by Nitrification-Denitrification Process. Water Res. 1992, 26, 1229-1236. [CrossRef]

16. Higgins, I.J.; Best, D.J.; Hammond, R.C.; Scott, D. Methane-oxidizing microorganisms. Microbiol. Rev. 1981, 45, 556-590.

17. Hoefman, S.; Van Der Ha, D.; Boon, N.; Vandamme, P.; De Vos, P.; Heylen, K. Niche differentiation in nitrogen metabolism among methanotrophs within an operational taxonomic unit. BMC Microbiol. 2014, 14, 83. [CrossRef] [PubMed]

18. Myszograj, S.; Płuciennik-Koropczuk, E.; Jakubaszek, A. COD fractions-Methods of measurement and use in wastewater treatment technology. Civ. Environ. Eng. Rep. 2017, 24.1, 195-206. [CrossRef]

19. Sadecka, Z.; Jêdrczak, A.; Płuciennik-Koropczuk, E.; Myszograj, S.; Suchowska-Kisielewicz, M. COD fractions in sewage flowing into Polish wastewater treatment plants. Chem. Biochem. Eng. Q. 2013, 27, 185-195.

20. Shah, M. Modified Ludzack Ettinger process-An innovation for removal of biological nitrogen. Austin J. Biotechnol. Bioeng. 2018, 5, 1094.

21. McCarty, P.L.; Beck, L.; St. Amant, P. Biological Denitrification of Agricultural Wastewaters by Addition of Organic Materials. In Proceedings of the 24th Annual Purdue Industrial Waste Conference, Purdue University, Lafayette, IN, USA, 6-7 May 1969; pp. 1271-1285.

22. Whittenbury, R.; Phillips, K.C.; Wilkinson, J.F. Enrichment, isolation and some properties of methane-utilizing bacteria. J. Gen. Microbiol. 1970, 61, 205-218. [CrossRef]

23. Bowman, J.P.; Sly, L.I.; Nichlols, P.D.; Hayward, A.C. Revised taxonomy of the methanotrophs: Description of methylobacter gen. nov., emendation of Methylococcus, validation of Methylosinus and Methylocystis species, and a proposal that the family Methylococcaceae includes only the group I Methanotrophs. Int. J. Syst. Bacteriol. 1993, 43, 735-753. [CrossRef]

24. Wartiainen, I.; Hestnes, A.G.; McDonald, I.R.; Svenning, M.M. Methylobacter tundripaludum sp. nov., a methane-oxidizing bacterium from Arctic wetland soil on the Svalbard islands, Norway (78 N). Int. J. Syst. Evol. Microbiol. 2006, 56, 109-113.

25. Tavormina, P.L.; Ussler, W.; Joye, S.B.; Harrison, B.K.; Orphan, V.J. Distributions of putative aerobic methanotrophs in diverse pelagic marine environments. ISME J. 2010, 4, 700-710. [CrossRef]

26. Mcdonald, I.; Smith, K.; Lidstrom, M. Methanotrophic populations in estuarine sediment from Newport Bay, California. FEMS Microbiol. Lett. 2005, 250, 287-293. [CrossRef]

27. Flynn, J.; Hirayama, H.; Sakai, Y.; Dunfield, P.; Klotz, M.; Knief, C.; Op den Camp, H.; Jetten, M.; Khmelenina, V.; Trotsenko, Y.; et al. Draft genome sequences of gammaproteobacterial methanotrophs isolated from marine ecosystems: TABLE 1. Genome Announc. 2016, 4, e01629-15. [CrossRef]

28. Han, J.-S.; Ahn, C.-M.; Mahanty, B.; Kim, C.-G. Partial oxidative conversion of methane to methanol through selective inhibition of methanol dehydrogenase in methanotrophic consortium from landfill cover soil. Appl. Biochem. Biotechnol. 2013, 171, 1487-1499. [CrossRef] [PubMed]

29. Hwang, I.Y.; Lee, S.H.; Choi, Y.S.; Park, S.J.; Na, J.G.; Chang, I.S.; Kim, C.; Kim, H.C.; Kim, Y.H.; Lee, J.W.; et al. Biocatalytic conversion of methane to methanol as a key step for development of methane-based biorefineries. J. Microbiol. Biotechnol. 2014, 24, 1597-1605. [CrossRef] [PubMed]

30. Kim, H.G.; Han, G.H.; Kim, S.W. Optimization of lab scale methanol production by Methylosinus trichosporium OB3b. Biotechnol. Bioprocess Eng. 2010, 15, 476-480. [CrossRef]

31. Yoo, Y.-S.; Han, J.-S.; Ahn, C.-M.; Min, D.-H.; Mo, W.-J.; Yoon, S.U.; Lee, J.-G.; Lee, J.-Y.; Kim, C.-G. Characteristics of methanol production derived from methane oxidation by inhibiting methanol dehydrogenase. J. Korean Soc. Environ. Eng. 2011, 33, 662-669. [CrossRef]

32. Yoo, Y.-S.; Han, J.-S.; Ahn, C.-M.; Kim, C.-G. Comparative enzyme inhibitive methanol production by Methylosinus sporium from simulated biogas. Environ. Technol. 2014, 36, 1-22.

33. Patel, S.; Mardina, P.; Kim, S.-Y.; Lee, J.-K.; Kim, I.-W. Biological methanol production by a type II methanotroph Methylocystis bryophila. J. Microbiol. Biotechnol. 2016, 26, 712-724. [CrossRef]

34. Anthony, C. The Biochemistry of Methylotrophs; Academic Press: Cambridge, MA, USA, 1982; ISBN 012058820X.

35. Kim, I.-T.; Lee, Y.-E.; Yoo, Y.-S.; Jeong, W.; Yoon, Y.-H.; Shin, D.-C.; Jeong, Y. Development of a combined aerobic-anoxic and methane oxidation bioreactor system using mixed methanotrophs and biogas for wastewater denitrification. Water 2019, 11, 1377. [CrossRef]

36. Bédard, C.; Knowles, R. Physiology, biochemistry, and specific inhibitors of $\mathrm{CH}_{4}, \mathrm{NH}^{4+}$, and CO oxidation by methanotrophs and nitrifiers. Microbiol. Rev. 1989, 53, 68-84. 
37. Carlsen, H.N.; Joergensen, L.; Degn, H. Inhibition by ammonia of methane utilization in Methylococcus capsulatus (Bath). Appl. Microbiol. Biotechnol. 1991, 35, 124-127. [CrossRef]

38. Zheng, Y.; Huang, R.; Wang, B.Z.; Bodelier, P.L.E.; Jia, Z.J. Competitive interactions between methane- and ammonia-oxidizing bacteria modulate carbon and nitrogen cycling in paddy soil. Biogeosciences 2014, 11, 3353-3368. [CrossRef]

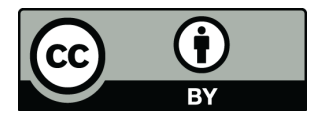

(C) 2019 by the author. Licensee MDPI, Basel, Switzerland. This article is an open access article distributed under the terms and conditions of the Creative Commons Attribution (CC BY) license (http://creativecommons.org/licenses/by/4.0/). 